\title{
On-farm Participatory Evaluation of Technologies for Soil Fertility Man- agement in the Sahel, West Africa
}

\author{
Hide Omae $^{1, *}$, A. K. Saidou ${ }^{2}$, I. Germaine ${ }^{2}$ and Satoshi Tobita ${ }^{3}$ \\ ${ }^{I}$ Tropical Agriculture Research Front (TARF), Japan International Research Center for Agricultural Sciences (JIR- \\ CAS), Ishigaki, Japan \\ ${ }^{2}$ National Institute of Agronomic Research of Niger (INRAN), Niamey, Niger \\ ${ }^{3}$ Crop, Livestock and Environment Division, JIRCAS, Tsukuba, Japan
}

\begin{abstract}
We conducted on-farm participatory experiments over three years at six villages in the Fakara commune of Western Niger to demonstrate, verify, and evaluate the relevance of soil fertility management methods based on millet/cowpea intercropping. We tested six methods using one of three organic fertilizers (millet husks, manure, or neither) with or without mineral fertilizer and one using millet/hibiscus intercropping with millet husks. We evaluated farmers' preferences by measuring the self-selected proportions of plots that farmers used for each condition. The results demonstrate the effectiveness of millet/cowpea intercropping; the application of mineral fertilizer, manure, and millet husks; and alternating-year application-all of them are affordable for farmers in the Sahel. Both the demonstration and farmerdirected trials made farmers aware of the effects of these methods. Farmers' selection of methods depended on availability. The dissemination of agricultural methods mainly depends on the availability of input materials in the absence of other constraints such as money and accessibility.
\end{abstract}

Keywords: Mother baby trial, Participatory approach, Soil fertility, Ssahel.

\section{INTRODUCTION}

Soil fertility in sub-Saharan Africa has traditionally been managed by shifting cultivation $[1,2]$. However, population pressure [3] has increased the demand for cropland, leading to a decrease in fallowing $[4,5]$, which has consequently reduced crop yields and soil fertility [6,7]. The benefits of intercropping of cereals and grain legumes [8-10] and cereal-legume rotations $[11,12]$ as well as the application of mineral fertilizer [13], crop residues [3, 14], manure [15, 16], and fertilizer combinations [17] have been proven. However, in addition to being available to local farmers $[4,18]$, such methods must also be affordable. Factors including poverty and scarcity of resources such as labor or draft power can constrain the dissemination of such methods [19].

A participatory approach is one way to improve the relevance and adoption of agricultural methods [20]. Participatory research has demonstrably improved the cultivar selection process $[21,22]$. In contrast, soil fertility methods are harder to disseminate because of the requirements of land, labor, and cash resources, with few successful models to follow [23].

\footnotetext{
*Address correspondence to this author at the Tropical Agriculture Research Front (TARF), Japan International Research Center for Agricultural Sciences (JIRCAS), 1091-1, Maezato-Kawarabaru, Ishigaki, Okinawa, 9070002, Japan; Tel.: +81-980-82-2314; E-mail: homae@affrc.go.jp
}

Therefore, this study evaluated soil fertility management methods in the Sahel in Western Africa, taking into consideration affordability, and clarified factors involved in the dissemination of these methods to local farmers through a participatory approach.

\section{MATERIALS AND METHODS}

\subsection{Site Descriptions}

On-farm experiments were conducted from 2007-2009 under rainfed conditions in the form of mother-baby trials [24] in six villages (Maourey Kouara Zeno: $13^{\circ} 35.02^{\prime} \mathrm{N}$, $2^{\circ} 38.78^{\prime} \mathrm{E}$; Katanga: $13^{\circ} 32.29^{\prime} \mathrm{N}, 2^{\circ} 49.43^{\prime} \mathrm{E}$; Tchigo Tegui: $13^{\circ} 30.65^{\prime} \mathrm{N}, 2^{\circ} 47.95^{\prime} \mathrm{E}$; Yerimadey: $13^{\circ} 28.65^{\prime} \mathrm{N}, 2^{\circ} 42.25^{\prime} \mathrm{E}$; Bokkosay: $13^{\circ} 25.13^{\prime} \mathrm{N}, 2^{\circ} 47.27^{\prime} \mathrm{E}$; Kodey: $13^{\circ} 23.50^{\prime} \mathrm{N}$, $\left.2^{\circ} 49.23^{\prime} \mathrm{E}\right)$ of the Fakara commune, Dantiandou district, Tillabéri region, Western Niger, approximately $50 \mathrm{~km}$ northeast of Niamey, the capital (Fig. 1).

There were 61, 66, 134, 90, 51, and 105 households in Maourey Kouara Zeno, Katanga, Tchigo Tegui, Yerimadey, Bokkosay, and Kodey, respectively. The Zarma, the principal ethnic group in this area, are agriculturalists engaged mainly in rainfed grain production and principally grow millet (Pennisetum glaucum (L.) R.Br.) and cowpea (Vigna unguiculata (L.) Walp.). The prevailing soil type in Fakara is psammentic paleudalfs with a high sand fraction and typical 


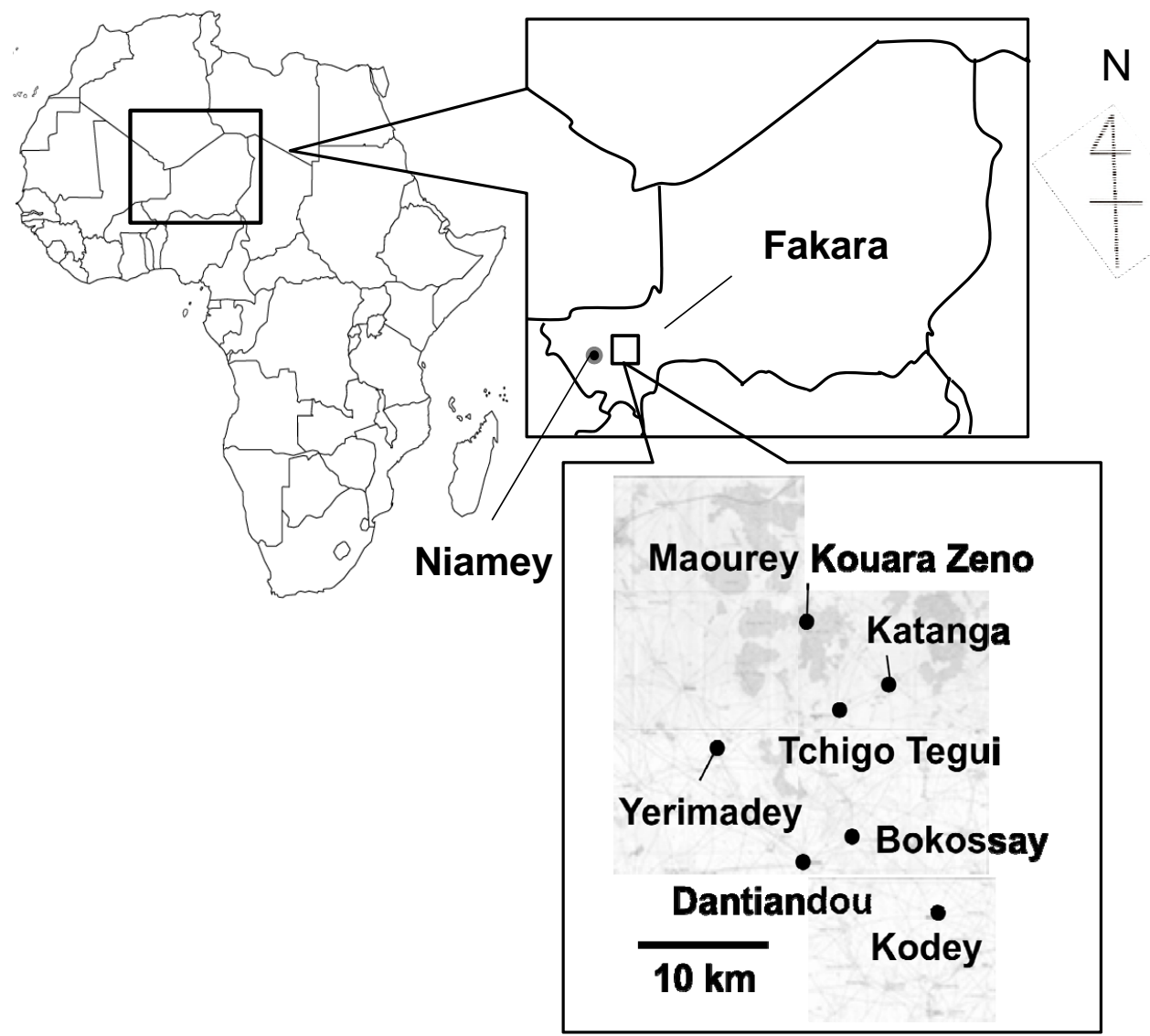

Fig. (1). Location of the experiments and demonstration sites.

characteristics of an infertile soil [25, 26]. Rain falls from June until September, peaking August, bringing an annual total of approximately $550 \mathrm{~mm}$ [25]. From 2001-2007, the annual average rainfall at Kodey was $435 \mathrm{~mm}$. In 2008 and 2009, the annual rainfall was 442 and 516 mm during 38 and 45 days of rain, respectively; the minimum and maximum annual temperatures in 2008 and 2009 were $23^{\circ} \mathrm{C}$ and $31^{\circ} \mathrm{C}$, and $23^{\circ} \mathrm{C}$ and $36^{\circ} \mathrm{C}$, respectively.

\subsection{Participatory Approach to Experiments, Demonstra- tion, and Practices}

Farmers often use mother-baby trials for crop cultivar selection [24]. We used this method to evaluate farmers' selection of millet/cowpea intercrop methods on one or two farms in each village, which were designated mother trial fields (Table 1).

First, we conducted 1- to 3-day training courses for farmers in each village in March or April 2008-2010. These courses presented the types and effects of organic and mineral fertilizers, micro-dosing of mineral fertilizers [27, 28], corralling for direct application of manure to fields, differences between traditional and advanced composts, characteristics of improved cowpeas, and the use of intercropping to about 25 farmers (all men) in each village. We subsequently invited the farmers to try the methods of their choice on their own farms; these fields were designated baby trial fields with reference to the mother trials. The results of the mother trials were presented to the farmers on field days held in the mother trial fields in October or November 2008 and 2009. The farmers reviewed the results of the baby trials at meetings in February 2009 and April 2010.

\subsection{Field Experiment Design}

\subsubsection{Mother Trials}

Seven $20 \times 20$-m plots were established in each mother trial field in each village in 2008 (Table 1). Six of them received one of six combined fertilizer treatments: three forms of organic fertilizer (millet husks, manure, or neither) with or without mineral fertilizer; a millet ("Haini Tchirey," 120 days to harvest)/cowpea intercrop was grown using a local cowpea landrace. The other plot grew a millet/hibiscus $(\mathrm{Hi}$ biscus sabdariffa "Wankoye") intercrop with millet husks. In 2009 , the seven plots were each divided into two $(9.5 \times 20$ $\mathrm{m}$ ); half of each plot was fertilized as in 2008, and the other half was not fertilized. The millet crops received $9 \mathrm{t} / \mathrm{ha}$ cow manure $(109.8 \mathrm{~kg} \mathrm{~N} / \mathrm{ha})$ or $6 \mathrm{t} / \mathrm{ha}$ millet husks $(41.4 \mathrm{~kg}$ N/ha). Mineral fertilizer comprised $3 \mathrm{~g}$ compound fertilizer $(\mathrm{N}: \mathrm{P}: \mathrm{K}=15: 15: 15)$ per hill at sowing and $2 \mathrm{~g}$ urea at first weeding (13.7 kg N/ha) applied by using a micro-dosing technique $[27,28]$. Although the application dose of nitrogen differed among the organic and inorganic fertilizers, we respected the ways of farmers in this region and thus did not adjust application doses to ensure a standardized amount of 
Table 1. Combination of technologies demonstrated at mother fields, Fakara, Niger.

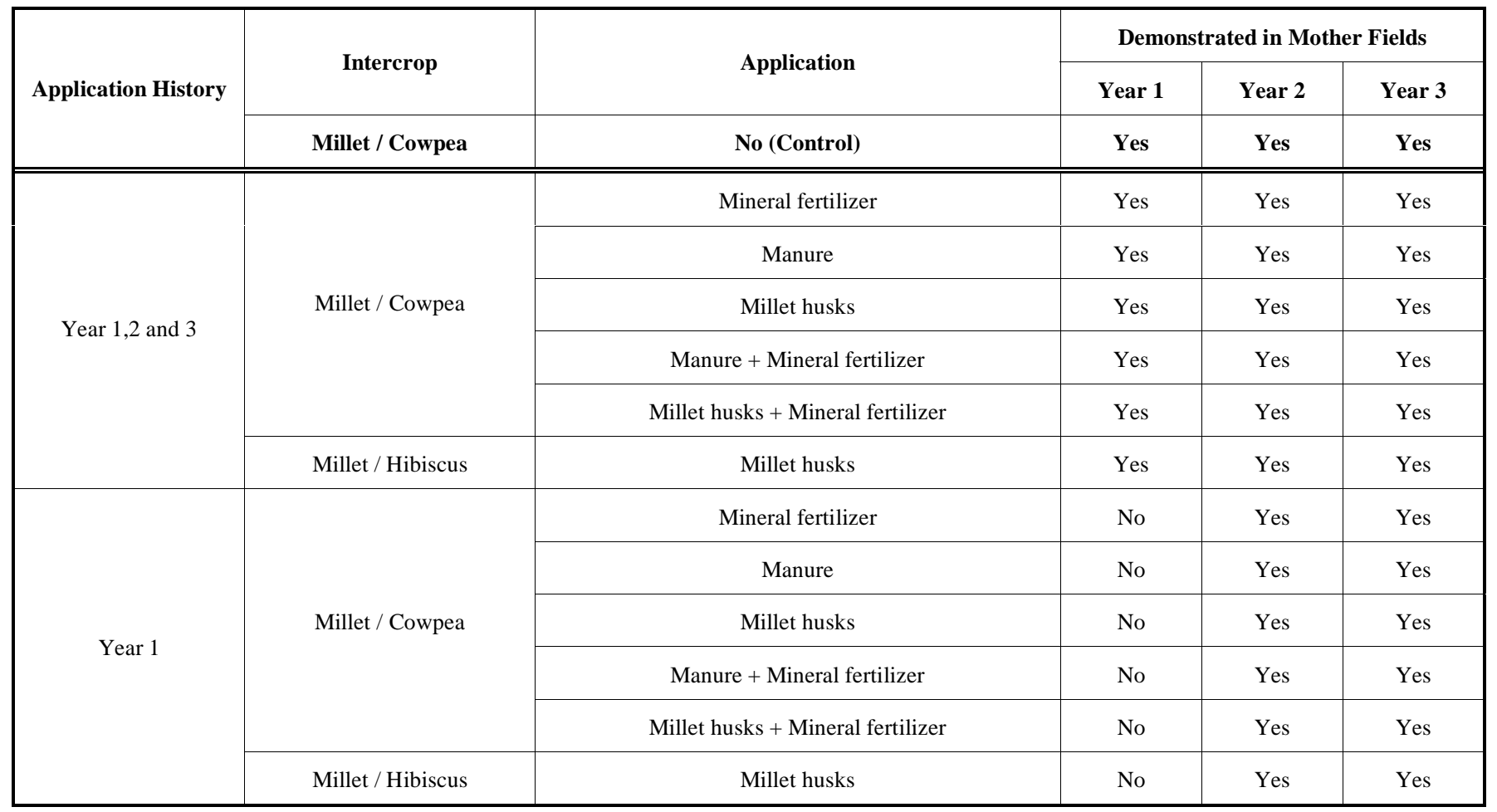

$9 \mathrm{t} / \mathrm{ha}$ of manure and $6 \mathrm{t} / \mathrm{ha}$ of millet husks were applied before sowing millet.

For mineral fertilizer, $3 \mathrm{~g}$ of N:P2O5:K2O (15:15:15)/hill was applied at sowing, and $2 \mathrm{~g}$ of Urea was applied at 1st weeding (one month after of the sowing).

nitrogen. The experiments were conducted in a split-plot design with four to six replicates (i.e., one or two per village). Millet was sown at $1.0 \times 1.0 \mathrm{~m}$ in June each year, thinned to three plants per hill after 2 weeks, and harvested in October. Cowpea and hibiscus were sown at $1.0 \times 1.0 \mathrm{~m}$ between millet hills in July each year and harvested in October. At physiological maturity, millet plants in each plot were harvested and partitioned into ears and stalks. After drying, the ears were threshed, and the total biomass was determined. Cowpea and hibiscus plants were also harvested at physiological maturity and partitioned into fodder and pods. After drying, the pods were threshed. All aboveground crop residues were removed from the plots at the end of each cropping season.

The differences between treatments were determined by ANOVA followed by Student's $t$-test in JMP version 9.0.0 software (SAS Institute, Cary, NC, USA).

\subsubsection{Baby Trials}

In 2008, 2009, and 2010, 62 farmers from all six villages, 76 from four villages, and 72 from four villages participated in the baby trials, respectively; they selected an average of 4.1, 4.7, and 4.6 methods, respectively. The plot size for each method was $10 \times 10 \mathrm{~m}$. Sowing, harvesting, and all measurements were performed with reference to the mother trial field in each village.

\subsection{Farmer Survey}

After training and before the baby trials in 2008, we interviewed the attending farmers and gathered information about them, their families, and their farms. After establishing the baby trials, we divided the data between baby trial farmers (baseline data) and non-participating farmers as controls. Fertilizer application was classified as manure, millet husks, mineral fertilizer, corralling, combinations thereof, or other (i.e., house dust, human excrement, and compost).

To gauge the use of mineral fertilizer, we visited a local store in each village in 2008 and interviewed an average of 8.8 farmers who came to purchase mineral fertilizer to gather information about fertilizer use. Additional farmers were interviewed if numbers were low.

Regarding the detailed analysis on farmers' selection of millet husks as well as the relationships among the locations of granaries, threshing floors, and baby trial fields, we selected Kodey as a representative of a typical traditional village in this region; it is moderately isolated from the other villages and is thus not excessively developed. We recorded locations by using a portable GPS receiver (Genie GT-31, Locosys, Taipei, Taiwan) in 2008.

\section{RESULTS}

\subsection{Mother Trials}

When fertilizer treatments were applied in Years 1 and 2, relative to millet/hibiscus intercropping, millet/cowpea intercropping increased millet biomass by $57 \%(P<0.10)$ and millet yield by $73 \%(P<0.10)$ in Year 2 but decreased cowpea yield by $78 \%(P<0.001)$ in Year 1 (Table 2). When treatments were applied in Year 1 only, the trends were similar but not significant. 
Table 2. Crop biomass and yield in different intercrop of mother fields, Fakara, Niger.

\begin{tabular}{|c|c|c|c|c|c|c|c|c|c|c|c|}
\hline \multirow{3}{*}{$\begin{array}{c}\text { Application } \\
\text { History }\end{array}$} & \multirow{3}{*}{ Intercrop } & \multicolumn{6}{|c|}{ Biomass (kg/ha) } & \multicolumn{4}{|c|}{ Yield (kg/ha) } \\
\hline & & \multicolumn{2}{|c|}{ Total } & \multicolumn{2}{|c|}{ Millet } & \multicolumn{2}{|c|}{ Cowpea or Hibiscus } & \multicolumn{2}{|c|}{ Millet } & \multicolumn{2}{|c|}{ Cowpea or Hibiscus } \\
\hline & & Year 1 & Year 2 & Year 1 & Year 2 & Year 1 & Year 2 & Year 1 & Year 2 & Year 1 & Year 2 \\
\hline \multirow{3}{*}{ Year 1,2} & Millet / Cowpea & 1702 & 3108 & 1076 & $2766 a$ & 626 & 342 & 141 & $438 \mathrm{a}$ & $77 b$ & 39 \\
\hline & Millet / Hibiscus & 2002 & 2261 & 1147 & $1763 b$ & 855 & 499 & 180 & $253 b$ & $349 a$ & 98 \\
\hline & & n.s. & n.s. & n.s. & $*$ & n.s. & n.s. & n.s. & $*$ & $* * *$ & n.s. \\
\hline \multirow{3}{*}{ Year 1} & Millet / Cowpea & - & 2290 & - & 2117 & - & 172 & - & 268 & - & 39 \\
\hline & Millet / Hibiscus & - & 1868 & - & 1364 & - & 504 & - & 171 & - & 98 \\
\hline & & & n.s. & & n.s. & & n.s. & & n.s. & & n.s. \\
\hline
\end{tabular}

$*$ and $* * *$ indicate significantly different at 0.10 and 0.001 level, respectively while n.s. indicates no significantly different.

Different letters indicate statistically significant at 0.10 level (by Student $t$ test).

When fertilizer treatments were applied in Years 1 and 2, relative to the control, manure application increased total, millet, and cowpea or hibiscus biomass by $170-267 \%(P<$ $0.001), 212-284 \%(P<0.001)$, and $101 \%-105 \%$ (n.s. to $P<$ $0.05)$, respectively, and millet yield by $236-438 \%(P<0.01)$ (Table 3). Millet husks increased total, millet, and cowpea or hibiscus biomass by $52-125 \%$ (n.s. to $P<0.001$ ), $59-122 \%$ (n.s. $-P<0.001$ ), and $42-157 \%$ (n.s.), respectively, and millet yield by $26-184 \%$ (n.s.). Mineral fertilizer increased total and millet biomass by $84-98 \%$ (n.s. to $P<0.001$ ) and 109$113 \%$ (n.s. to $P<0.001$ ), respectively.

When fertilizer treatments were applied in Year 1 only, manure increased total biomass by $241 \%(P<0.001)$, millet biomass by $273 \%(P<0.01)$, and millet yield by $273 \%(P<$ $0.001)$. Millet husks increased total biomass by $85 \%$, millet biomass by $98 \%$, and millet yield by $50 \%$, although the differences were not significant.

\subsection{Baby Trials}

When fertilizer treatments were applied in Years 1 and 2, manure increased total and millet biomass by $57 \%$ $(P<0.001)$ and millet yield by $38-157 \%$ (n.s. to $P<0.001$, Table 4). Mineral fertilizer increased total and millet biomass by $112 \%(P<0.001)$ and millet yield by $49-262 \%$ (n.s. to $P<0.001)$.

When applied in Year 1 only, manure increased total biomass by $104 \%(P<0.001)$, millet biomass by $86 \%$ $(P<0.001)$, cowpea biomass by $181 \%(P<0.001)$, and millet yield by $72-100 \%$ (n.s. to $P<0.001$ ).

Millet husks increased total biomass by $71 \%(P<0.001)$, millet biomass by $42 \%$ (n.s.), cowpea biomass by $188 \%$ $(P<0.001)$, millet yield by $48 \%$ (n.s.), and cowpea yield by $81 \%$ (n.s.). Mineral fertilizer increased total biomass by $84 \%$ $(P<0.001)$, cowpea biomass by $262 \%(P<0.001)$, millet yield by $26-126 \%$ (n.s. to $P<0.01$ ), and cowpea yield by 39-106\% (n.s. to $P<0.01)$.

\subsection{Characteristics of Baby Trial and Control Farmers}

There were no significant differences between baby trial and control farmers with respect to age, number of family members, group membership, livestock holdings, or building ownership (Table 5). Baby trial and control farmers had a mean of 3.1 and 4.9 fields, respectively, and grew a mean of 1.8 and 1.1 crops per field, respectively.

Baby trial and control farmers applied a mean of 1.9 and 0.9 types of fertilizers per field, respectively.

\subsection{Selection of Methods by Baby Trial Farmers}

Farmers' crop selections in Year 1 were mostly similar to their baseline preferences, except that they significantly increased millet planting and decreased planting of groundnut monocrops and other crops (Table 6).

Other crops included maize, sorghum, and hibiscus monocrops as well as combinations of okra and other vegetables, groundnut/bambara bean/okra, and bambara bean/sesame. Relative to initial planting, the proportion of millet monocrops increased by $361 \%(P<0.01)$ in Year 1 , decreased slightly in Year 2, and fell below the control and baseline levels in Year 3. The proportions of groundnut monocrops and others decreased to almost zero in Year 1 and remained lower than the controls.

The proportion of land planted with millet/cowpea eventually exceeded the control by $170 \%(P<0.001)$ in Year 3 (Table 6). In contrast, the proportion of land planted with millet/hibiscus fell in Years 1 and $2(P<0.05)$.

Farmers' selections of fertilizer between baseline preferences and Year 1 were similar, except that they abandoned others + mineral fertilizer and increased the use of mineral fertilizer alone by $271 \%(P<0.001)$ to the same level as the control. However, their use of mineral fertilizer alone subsequently returned to baseline in Years 2 and 3 (Table 7). Mineral fertilizer was applied to $65.8 \%$ of control fields but $49.4 \%$ of baby trial fields. Among baby trial farmers, the use of others + mineral fertilizer decreased from $15.4 \%$ initially to $0 \%$, which was not significantly different from the control.

In parallel with the large increase in the use of a single application of mineral fertilizer by baby trial farmers in Year 1 followed by a return to baseline in Years 2 and 3, the use of corralling alone, manure alone, and millet husks alone 
Table 3. Crop biomass and yield in different applications of mother fields, Fakara, Niger.

\begin{tabular}{|c|c|c|c|c|c|c|c|c|c|c|c|}
\hline $\begin{array}{l}\text { Application } \\
\text { History }\end{array}$ & Application & \multicolumn{6}{|c|}{ Biomass (kg/ha) } & \multicolumn{4}{|c|}{ Yield (kg/ha) } \\
\hline \multirow{4}{*}{ Year 1, 2} & No (Control) & $1117 \mathrm{c}$ & $1379 d$ & $675 c$ & $1246 \mathrm{~d}$ & $442 c$ & 133 & $112 \mathrm{~b}$ & $154 \mathrm{c}$ & 66 & $30 \mathrm{~b}$ \\
\hline & Mineral fertilizer & $2052 \mathrm{bc}$ & $2725 \mathrm{c}$ & $1440 \mathrm{bc}$ & $2603 c$ & $611 b c$ & 122 & $277 \mathrm{ab}$ & $366 \mathrm{bc}$ & 52 & $18 \mathrm{~b}$ \\
\hline & Millet husks & $1702 \mathrm{c}$ & $3108 \mathrm{bc}$ & $1076 \mathrm{c}$ & $2766 c$ & $626 \mathrm{bc}$ & 342 & $141 \mathrm{~b}$ & $438 \mathrm{bc}$ & 77 & $39 b$ \\
\hline & $\begin{array}{c}\text { Manure + Mineral } \\
\text { fertilizer }\end{array}$ & $4080 \mathrm{a}$ & $4380 \mathrm{ab}$ & $2863 a$ & $4145 \mathrm{ab}$ & $1217 \mathrm{a}$ & 236 & $406 \mathrm{a}$ & $546 \mathrm{ab}$ & 83 & $27 b$ \\
\hline \multirow{6}{*}{ Year 1} & No (Control) & - & $1237 \mathrm{c}$ & - & $1067 \mathrm{c}$ & - & 170 & - & $179 b$ & - & 37 \\
\hline & Mineral fertilizer & - & $1888 \mathrm{c}$ & - & $1740 \mathrm{c}$ & - & 147 & - & $214 b$ & - & 32 \\
\hline & Manure & - & $4213 a$ & - & $3982 \mathrm{a}$ & - & 232 & - & $668 \mathrm{a}$ & - & 65 \\
\hline & Millet husks & - & $2290 \mathrm{c}$ & - & $2117 \mathrm{c}$ & - & 172 & - & $268 b$ & - & 39 \\
\hline & $\begin{array}{c}\text { Manure + Mineral } \\
\text { fertilizer }\end{array}$ & - & $3567 \mathrm{ab}$ & - & $3262 \mathrm{ab}$ & - & 305 & - & $570 \mathrm{a}$ & - & 61 \\
\hline & $\begin{array}{l}\text { Millet husks + } \\
\text { Mineral fertilizer }\end{array}$ & - & $2425 b c$ & - & $2221 b c$ & - & 204 & - & $314 b$ & - & 39 \\
\hline
\end{tabular}

$*, * *$ and $* * *$ indicate significantly different at $0.05,0.01$ and 0.001 level, respectively while $n$.s. indicates no significantly different.

Different letters indicate statistically significant at 0.05 level (by Student $t$ test).

increased, although only the latter increased significantly (Table 7). In contrast, the use of manure + millet husks + mineral fertilizer decreased to below the control level, and the use of corralling + manure + mineral fertilizer remained below the control level (both $P<0.05$ ). The use of cow dung (i.e., manure + corralling) decreased slightly in Year 1 $(31.6 \%)$ relative to both baseline $(40.4 \%)$ and control $(42.6 \%)$ levels, and subsequently increased in Year 2 $(50.8 \%)$ and Year $3(51.9 \%)$. Relative to baseline, the use of millet husks increased by up to $1943 \%$ to about double the control level.

The use of three or more fertilizers was rare in the baby trials (Table 7). The percentage of "Applied in Year 1" was significantly greater in Year 3 than those in the baseline and the control (Table 7).

\section{DISCUSSION AND CONCLUSION}

The differences in crop selection between baseline preferences and Year 1 (Table 6) might be explained by the farmers' greater focus on soil fertility management by fertilizer application than by intercropping with legumes; in particular, they may have selected millet monocropping to determine the effect of fertilizer application more simply.
However, the proportion of millet monocropping decreased from Year 2, while millet/cowpea intercropping increased. We suppose that the farmers became aware of the greater effectiveness of millet/cowpea than millet/hibiscus intercropping on the basis of the results of the mother trials (Table 2).

The proportion of land planted with millet/cowpea eventually exceeded that of the control by $170 \%(P<0.001)$ in Year 3 (Table 6). In contrast, that of millet/hibiscus fell in Years 1 and $2(P<0.05)$. These trends can be explained according to the results of the mother trials: millet/cowpea gave a better millet yield than millet/hibiscus (Table 2). Therefore, the baby trial farmers focused more on millet/cowpea.

The baby trial and control farmers had a mean of 3.1 and 4.9 fields, and grew 1.8 and 1.1 crops per field, respectively (Table 5). The baseline preferences of baby trial farmers were largely similar to those of the control farmers, except that they grew less sesame and more other crops (Table 6). These results suggest the baby trial farmers had greater crop diversity per field than the control farmers.

Our survey of farmers who visited a local store to buy mineral fertilizer revealed that $42 \%$ of farmers were using 
Table 4. Crop biomass and yield in different applications of baby fields, Fakara, Niger.

\begin{tabular}{|c|c|c|c|c|c|c|c|c|}
\hline \multirow{3}{*}{$\begin{array}{l}\text { Application } \\
\text { History }\end{array}$} & \multirow{3}{*}{ Application } & \multicolumn{3}{|c|}{ Biomass (kg/ha) } & \multicolumn{4}{|c|}{ Yield (kg/ha) } \\
\hline & & \multirow{2}{*}{$\begin{array}{c}\text { Total } \\
\text { Year } 2\end{array}$} & \multirow{2}{*}{$\begin{array}{l}\text { Millet } \\
\text { Year } 2\end{array}$} & \multirow{2}{*}{$\begin{array}{c}\text { Cowpea } \\
\text { Year } 2\end{array}$} & \multicolumn{2}{|c|}{ Millet } & \multicolumn{2}{|c|}{ Cowpea or Hibiscus } \\
\hline & & & & & Year 1 & Year 2 & Year 1 & Year 2 \\
\hline \multirow{9}{*}{ Year 1,2} & No (Control) & $1800 f$ & $1800 f$ & - & 660 & $295 \mathrm{e}$ & - & - \\
\hline & Mineral fertilizer & $3818 b c$ & $3818 b c$ & - & 984 & $1069 \mathrm{ab}$ & - & - \\
\hline & Manure & 2823de & $2823 \mathrm{de}$ & - & 913 & $757 \mathrm{~cd}$ & - & - \\
\hline & Corralling & $4414 \mathrm{ab}$ & $4414 \mathrm{ab}$ & - & 670 & $940 \mathrm{bc}$ & - & - \\
\hline & Millet husks & $1900 \mathrm{ef}$ & $1900 \mathrm{ef}$ & - & 485 & $395 \mathrm{de}$ & - & - \\
\hline & Manure + Mineral fertilizer & $3558 \mathrm{~cd}$ & $3558 \mathrm{~cd}$ & - & 1057 & $956 \mathrm{bc}$ & - & - \\
\hline & $\begin{array}{c}\text { Corralling }+ \text { Mineral fertil- } \\
\text { izer }\end{array}$ & $4943 a$ & $4943 a$ & - & 1913 & $1237 \mathrm{a}$ & - & - \\
\hline & $\begin{array}{c}\text { Millet husks + Mineral fertil- } \\
\text { izer }\end{array}$ & $2598 \mathrm{cdef}$ & $2598 \mathrm{cdef}$ & - & 1469 & $640 \mathrm{cde}$ & - & - \\
\hline & & $* * *$ & $* * *$ & & n.s. & $* * *$ & & \\
\hline \multirow{9}{*}{ Year 1} & No (Control) & $2393 d$ & $1926 \mathrm{c}$ & $466 \mathrm{c}$ & $541 \mathrm{c}$ & $340 \mathrm{e}$ & 198 & $159 \mathrm{c}$ \\
\hline & Mineral fertilizer & $4394 b c$ & $2706 \mathrm{c}$ & $1688 \mathrm{a}$ & $1224 \mathrm{ab}$ & $429 \mathrm{e}$ & 275 & $328 \mathrm{ab}$ \\
\hline & Manure & $4890 b$ & $3580 \mathrm{~b}$ & $1310 \mathrm{ab}$ & $928 b c$ & $679 d$ & 398 & $229 b c$ \\
\hline & Corralling & $4522 \mathrm{bc}$ & $4001 b$ & $521 \mathrm{c}$ & - & $1137 \mathrm{a}$ & - & $194 \mathrm{c}$ \\
\hline & Millet husks & $4084 c$ & $2742 c$ & $1342 \mathrm{ab}$ & - & $504 \mathrm{e}$ & - & $288 b c$ \\
\hline & Manure + Mineral fertilizer & $5964 a$ & $4967 \mathrm{a}$ & $997 b c$ & $1715 \mathrm{a}$ & $889 b c$ & 420 & $194 \mathrm{c}$ \\
\hline & Corraling + Mineral fertilizer & $4830 \mathrm{abc}$ & $4037 \mathrm{ab}$ & $793 b c$ & - & $1180 \mathrm{ab}$ & - & 299abc \\
\hline & $\begin{array}{c}\text { Millet husks }+ \text { Mineral fertil- } \\
\text { izer }\end{array}$ & $5028 \mathrm{ab}$ & $3750 \mathrm{~b}$ & $1278 \mathrm{ab}$ & - & $759 \mathrm{~cd}$ & - & $402 \mathrm{a}$ \\
\hline & & $* * *$ & $* * *$ & $* * *$ & $* *$ & $* * *$ & n.s. & $* *$ \\
\hline
\end{tabular}

$*, * *$ and $* * *$ indicate significantly different at $0.05,0.01$ and 0.001 level, respectively while $\mathrm{n} . \mathrm{s}$. indicates no significantly different.

Different letters indicate statistically significant at 0.05 level (by Student $t$ test).

Table 5. Basically agricultural information on baby and non-baby farmers, Fakara, Niger.

\begin{tabular}{|c|c|c|c|c|c|c|c|c|c|c|c|c|}
\hline \multirow[b]{2}{*}{$\begin{array}{c}\text { Baby or Non- } \\
\text { baby }\end{array}$} & \multirow[b]{2}{*}{ Age } & \multirow[b]{2}{*}{$\begin{array}{c}\text { Family } \\
\text { NO }\end{array}$} & \multirow{2}{*}{$\begin{array}{l}\text { Partici- } \\
\text { pation of } \\
\text { farmers } \\
\text { group }(\%)\end{array}$} & \multicolumn{3}{|c|}{ Livestock } & \multicolumn{3}{|c|}{ Building } & \multicolumn{3}{|c|}{ Field } \\
\hline & & & & $\begin{array}{c}\text { Cow NO } \\
(\%)\end{array}$ & $\begin{array}{c}\text { Other } \\
\text { Ruminants } \\
\text { NO }(\%)\end{array}$ & $\begin{array}{c}\text { Domestic } \\
\text { poetry NO } \\
(\%)\end{array}$ & $\begin{array}{c}\text { House } \\
\text { NO } \\
(\%)\end{array}$ & $\begin{array}{l}\text { Hangar } \\
\text { NO }(\%)\end{array}$ & $\begin{array}{l}\text { Granary } \\
\text { NO (\%) }\end{array}$ & $\begin{array}{l}\text { Fields } \\
\text { NO }\end{array}$ & $\begin{array}{c}\text { Crops NO / } \\
\text { field }\end{array}$ & $\begin{array}{l}\text { Fertilizer } \\
\text { NO /field }\end{array}$ \\
\hline Baby farmer & 39.0 & 9.0 & 95.5 & $\begin{array}{c}8.3 \\
(48.1)\end{array}$ & $5.7(69.9)$ & $7.2(77.0)$ & $\begin{array}{c}1.3 \\
(77.2)\end{array}$ & $\begin{array}{c}1.1 \\
(40.6)\end{array}$ & $2.0(82.7)$ & $3.1 \mathrm{~b}$ & $1.8 \mathrm{a}$ & $1.9 \mathrm{a}$ \\
\hline Non-baby farmer & 38.7 & 8.8 & 87.7 & $\begin{array}{c}4.8 \\
(50.9)\end{array}$ & $4.2(73.9)$ & $6.1(71.3)$ & $\begin{array}{c}1.4 \\
(80.9)\end{array}$ & $\begin{array}{c}1.4 \\
(64.0)\end{array}$ & $1.5(91.7)$ & $4.9 \mathrm{a}$ & $1.1 \mathrm{~b}$ & $0.9 \mathrm{~b}$ \\
\hline B & n.s. & n.s. & n.s. & n.s. & n.s. & n.s. & n.s. & n.s. & n.s. & $* *$ & $* *$ & $* *$ \\
\hline
\end{tabular}

$\mathrm{N}$ (average) $=9.8$ and 11.0 in baby and non-baby farmer, respectively.

** indicates significantly different at 0.01 level, while n.s. indicates no significantly different.

Different alphabets indicate statistically significant at 0.05 level (by Student $t$ test). 
Table 6. Percentage of Farmers trials in different cropping patterns of baby fields, Fakara, Niger.

\begin{tabular}{|c|c|c|c|c|c|c|c|c|c|c|c|c|c|c|c|}
\hline Year & $\begin{array}{l}\text { Millet / } \\
\text { Cowpea }\end{array}$ & $\begin{array}{l}\text { Millet / } \\
\text { Hibiscus }\end{array}$ & $\begin{array}{l}\text { Millet } \\
\text { Mono } \\
\text { Crop }\end{array}$ & $\begin{array}{c}\text { Bambara } \\
\text { bean } \\
\text { Mono } \\
\text { Crop }\end{array}$ & $\begin{array}{c}\text { Ground } \\
\text { nut } \\
\text { Mono } \\
\text { Crop }\end{array}$ & $\begin{array}{c}\text { Sesame } \\
\text { Mono } \\
\text { Crop }\end{array}$ & $\begin{array}{c}\text { Cowpea } \\
\text { Mono } \\
\text { Crop }\end{array}$ & $\begin{array}{c}\text { Millet / } \\
\text { Cowpea / } \\
\text { Hibiscus }\end{array}$ & $\begin{array}{l}\text { Millet / } \\
\text { Others }\end{array}$ & $\begin{array}{c}\text { Millet / } \\
\text { Cowpea / } \\
\text { Sorghum }\end{array}$ & $\begin{array}{c}\text { Millet / } \\
\text { Cowpea / } \\
\text { Sesame }\end{array}$ & $\begin{array}{c}\text { Cowpea / } \\
\text { Ground } \\
\text { nut }\end{array}$ & $\begin{array}{l}\text { Millet / } \\
\text { Sesame }\end{array}$ & Others & $\begin{array}{c}\text { Total } \\
(\%)\end{array}$ \\
\hline Initial & $34.7 \mathrm{c}$ & $17.7 \mathrm{ab}$ & $9.3 c$ & 7.9 & $5.2 \mathrm{a}$ & $2.2 b$ & 1.7 & 0.0 & 0.0 & 0.0 & 0.0 & 0.0 & 0.0 & $21.4 \mathrm{a}$ & 100.0 \\
\hline Year 1 & $42.1 \mathrm{bc}$ & $4.9 \mathrm{bc}$ & $42.9 \mathrm{a}$ & 0.0 & $0.3 b$ & $0.0 \mathrm{~b}$ & 4.4 & 3.3 & 1.1 & 0.5 & 0.3 & 0.3 & 0.0 & $0.0 \mathrm{~b}$ & 100.0 \\
\hline Year 2 & $62.2 b$ & $0.3 \mathrm{c}$ & $31.0 \mathrm{ab}$ & 0.5 & $0.0 \mathrm{~b}$ & $0.9 \mathrm{~b}$ & 2.8 & 0.0 & 0.9 & 0.0 & 0.0 & 0.0 & 1.4 & $0.0 \mathrm{~b}$ & 100.0 \\
\hline Year 3 & $89.4 \mathrm{a}$ & $6.3 \mathrm{abc}$ & $1.6 \mathrm{c}$ & 0.0 & $0.0 \mathrm{~b}$ & $0.0 \mathrm{~b}$ & 0.5 & 0.0 & 0.0 & 0.0 & 0.0 & 0.0 & 2.2 & $0.0 \mathrm{~b}$ & 100.0 \\
\hline Control & $33.1 \mathrm{c}$ & $20.8 \mathrm{a}$ & $16.5 \mathrm{bc}$ & 5.9 & $3.2 \mathrm{ab}$ & $7.3 \mathrm{a}$ & 4.0 & 0.0 & 0.0 & 0.0 & 0.0 & 0.0 & 0.0 & $9.3 b$ & 100.0 \\
\hline $\mathrm{Y}$ & $* * *$ & $*$ & $* *$ & n.s. & $* * *$ & $* *$ & n.s. & n.s. & n.s. & n.s. & n.s. & n.s. & n.s. & $* * *$ & - \\
\hline
\end{tabular}

$\mathrm{N}$ (average) $=60.8,42.5,89.5,82.0,54.8$ in Initial, 2008, 2009, 2010 and Control, respectively.

$*, * *, * * *$ indicate significantly different at $0.05,0.01$ and 0.001 level, respectively while n.s. indicates no significantly different.

Different alphabets indicate statistically significant at 0.05 level (by Student $t$ test).

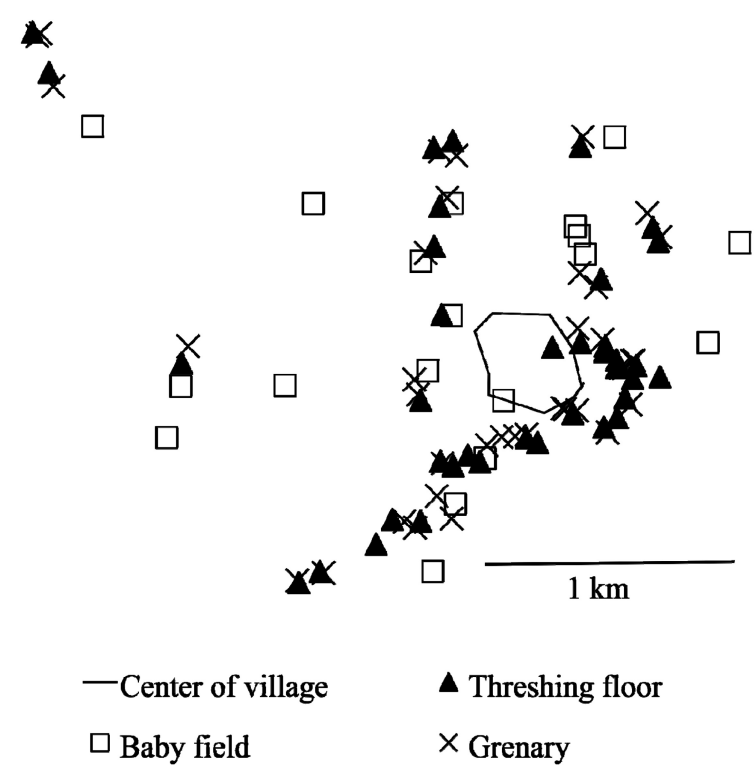

Fig. (2). Location of granary, threshing floor and baby field (Kodey, Fakara, 2009).

mineral fertilizer for the first time and that experienced farmers had been using it for an average of 4 years. Almost all farmers (94\%) mixed fertilizer with crop seeds, and all applied it at sowing; $71 \%$ learned about application methods such as micro-dosing through our training. All farmers applied mineral fertilizer to millet, $40 \%$ applied it to cowpea, and $85 \%$ expected higher yields. For $91 \%$ of farmers, insufficient money was the main constraint on mineral fertilizer use. Half $(53 \%)$ intended to keep using mineral fertilizers, and $43 \%$ wanted to expand their use. The survey results indicate the application of mineral fertilizer is relatively new to farmers in Fakara meaning that they do not know how to best apply it. Therefore, the baby trial farmers might have opted for a single application of mineral fertilizer in their trials to test it. Ease of handling of mineral fertilizer was another factor in its favorability. On the other hand, the control farmers were familiar with mineral fertilizer, applying it on its own and in combinations to $41.8 \%$ and $65.8 \%$ of their fields, respectively. All control farmers used mineral fertilizer, while $10-19 \%$ of baby trial farmers did not use it $(P<0.01)$.
Among baby trial farmers, the use of others + mineral fertilizer decreased from $15.4 \%$ initially to $0 \%$, which was not significantly different from the control farmers (Table 7). The baby trial and control farmers applied an average of 1.9 and 0.9 fertilizers per field, respectively (Table 5). Thus, the baby trial farmers appear to have favored a broader range of fertilizers than the control farmers.

The effects of the application of manure and millet husks were clear in both the mother and baby trials (Tables $\mathbf{3}, \mathbf{4}$ ). The results suggest that through observation and experience, the farmers changed their minds and selected manure and millet husks over single applications of mineral fertilizer. This decision is likely related to availability. All baby trial farmers grew millet, and $82.7 \%$ had access to a granary (Table 5) where the women thresh the millet and discard the husks. The baby trial fields, threshing floors, and granaries are all close to the village center (Fig. 2). This trend could be observed in the other villages in this region (personal communication). In addition, $48.1 \%$ and $69.9 \%$ of farmers have cows (8.3 on average) and other livestock (5.7 on average), 
Table 7. Percentage of farmers trials in different applications of baby fields, Fakara, Niger.

\begin{tabular}{|c|c|c|c|c|c|c|c|c|c|c|c|c|c|c|c|c|}
\hline \multicolumn{17}{|c|}{ Applied in Year 1, 2} \\
\hline $\begin{array}{c}\text { Fertilizer } \\
\text { Appli- } \\
\text { cation }\end{array}$ & $\begin{array}{c}\text { Millet } \\
\text { husks + } \\
\text { Mineral } \\
\text { fertilizer }\end{array}$ & $\begin{array}{c}\text { Others } \\
+ \text { Mineral } \\
\text { fertilizer }\end{array}$ & $\begin{array}{c}\text { No } \\
\text { (Control) }\end{array}$ & $\begin{array}{c}\text { Corralling } \\
\text { +Manure } \\
\text { +Millet } \\
\text { husks } \\
\text { +Mineral } \\
\text { fertilizer }\end{array}$ & $\begin{array}{l}\text { Mineral } \\
\text { fertilizer }\end{array}$ & $\begin{array}{c}\text { Corralling } \\
\text { +Millet } \\
\text { husks }\end{array}$ & Corralling & $\begin{array}{c}\text { Manure + } \\
\text { Millet } \\
\text { husks + } \\
\text { Mineral } \\
\text { fertilizer }\end{array}$ & $\begin{array}{l}\text { Corralling } \\
+ \text { Mineral } \\
\text { fertilizer }\end{array}$ & $\begin{array}{c}\text { Manure } \\
+ \text { Millet } \\
\text { husks }\end{array}$ & $\begin{array}{c}\text { Manure } \\
+ \\
\text { Mineral } \\
\text { fertil- } \\
\text { izer }\end{array}$ & Manure & $\begin{array}{c}\text { Corralling } \\
\text { +Millet } \\
\text { husks } \\
\text { +Mineral } \\
\text { fertilizer }\end{array}$ & Others & $\begin{array}{l}\text { Millet } \\
\text { husks }\end{array}$ & $\begin{array}{l}\text { Corralling } \\
\text { +Manure } \\
\text { +Mineral } \\
\text { fertilizer }\end{array}$ \\
\hline Initial & 18.9 & $15.4 \mathrm{a}$ & $12.0 \mathrm{a}$ & 11.7 & $11.4 \mathrm{~b}$ & 9.4 & 5.3 & $5.0 \mathrm{ab}$ & 3.1 & 1.8 & 1.5 & 1.3 & 0.0 & 1.3 & $0.7 \mathrm{~b}$ & $0.0 \mathrm{~b}$ \\
\hline Year 1 & 1.5 & $0.0 \mathrm{~b}$ & $18.9 \mathrm{a}$ & 0.0 & $42.3 \mathrm{a}$ & 0.0 & 1.9 & $0.0 \mathrm{~b}$ & 3.8 & 0.0 & 13.2 & 12.7 & 0.0 & 0.0 & $5.7 \mathrm{ab}$ & $0.0 \mathrm{~b}$ \\
\hline Year 2 & 8.7 & $0.0 \mathrm{~b}$ & $14.7 \mathrm{a}$ & 0.0 & $11.5 \mathrm{~b}$ & 0.0 & 17.4 & $0.4 \mathrm{~b}$ & 6.3 & 0.4 & 10.8 & 15.5 & 0.0 & 0.0 & $14.3 \mathrm{a}$ & $0.0 \mathrm{~b}$ \\
\hline Year 3 & 6.7 & $0.0 \mathrm{~b}$ & $10.4 \mathrm{a}$ & 0.0 & $12.4 \mathrm{~b}$ & 0.0 & 15.6 & $0.3 \mathrm{~b}$ & 4.4 & 0.3 & 13.5 & 17.8 & 0.0 & 0.0 & $14.1 \mathrm{a}$ & $0.0 \mathrm{~b}$ \\
\hline Control & 6.8 & $2.2 \mathrm{~b}$ & $0.0 \mathrm{~b}$ & 0.7 & $41.8 \mathrm{a}$ & 0.0 & 6.7 & $7.4 \mathrm{a}$ & 0.0 & 7.1 & 10.4 & 7.0 & 1.2 & 0.5 & $6.3 \mathrm{ab}$ & $2.1 \mathrm{a}$ \\
\hline A & n.s. & $* * *$ & $* *$ & n.s. & $* * *$ & n.s. & n.s. & $*$ & n.s. & n.s. & n.s. & n.s. & n.s. & n.s. & $*$ & $*$ \\
\hline
\end{tabular}

$\mathrm{N}$ (average) $=60.8,42.5,89.5,82.0,54.8$ in Initial, 2008, 2009, 2010 and Control, respectively.

$*, * *, * * *$ indicate significantly different at $0.05,0.01$ and 0.001 level, respectively while n.s. indicates no significantly different.

Different alphabets indicate statistically significant at 0.05 level (by Student t test).

which supply manure (Table 5). In contrast, farmers can afford to buy only a mean of $4.7 \mathrm{~kg}$ mineral fertilizer, which covers $<0.1$ ha by micro-dosing. This reflects the finding that $89 \%$ of farmers $(n=73)$ responded that money is the biggest limitation for the introduction of new technologies and methods.

Three or more fertilizers were rarely used in the baby trials (Table 7); although the farmers are familiar with combined fertilizer use, they likely wanted to identify the individual effect of each fertilizer.

The percentage of "Applied in Year 1" was significantly greater in Year 3 than those at baseline and the controls (Table 7). This reflects the results of both the mother and baby trials (Tables 3, 4). Moreover, this result indicates that farmers can be led to prefer a single application of fertilizer as long as the effect of the fertilizer lasts or application on alternating years.

The three major conclusions of the present study are as follows: (1) methods such as millet/cowpea intercropping; the application of mineral fertilizer, manure, and millet husks; and application in alternating years are affordable to farmers in the Sahel; (2) farmers become aware of the effects of technologies and methods through observation and experience; (3) the dissemination of technologies and methods mainly depends on the availability of inputs (e.g., crop residues, manure, seeds) in the absence of other constraints such as money and accessibility. Thus, an on-farm participatory evaluation system must be established and encouraged to confirm the long-term affordability of soil fertility management technologies and methods in the Sahel.

\section{CONFLICT OF INTERESTS}

The authors confirm that this article content has no conflicts of interest.

\section{ACKNOWLEDGEMENTS}

Declared none.

\section{REFERENCES}

[1] Malton P. Improving productivity in sorghum and pearl millet in Semi-Arid Africa. Food Res Inst Stud 1990; 22(1): 1-43.

[2] Rebafka FP, Hebel A, Bationo A, Stahr K, Marschner H. Short and long term effects of crop residues and of phosphorus fertilization on pearl millet yield on an acid sandy soil in Niger. Field Crop Res 1994; 36: 113-24.

[3] Bationo A, Mokwunye AU. Role of manures and crop residue in alleviating soil fertility constrains to crop production: with special reference to the Sahelian and Sudanian zones of West Africa. Fert Res 1991; 29: 117-25.

[4] McIntire J, Bourzat JD, Pingali P. Crop-livestock interaction in Sub-Saharan Africa. Washington, D. C., USA: The World Bank, 1992; pp. 1-246.

[5] Sanders J, Shapiro BI, Ramaswamy S. The economics of agricultural technology in Semi-Arid Sub-Saharan Africa. Baltimore, Maryland: Johns Hopkins University Press 1996.

[6] Abdoulaye T. Impact of opportunity cost of capital on adaptation of new technologies in the Birni N'Konni region of Niger. M. Sc thesis. Department of agricultural economics. West Lafayette, USA: Purdue University 1995.

[7] Abdoulaye T, Lowenberg-DeBoer J. Intensification of Sahelian farming systems: evidence from Niger. Agric Syst 2000; 64: 67-81.

[8] Ofori F, Stern WR. Cereal-legume intercropping system. Adv Agron 1987; 41: 41-90.

[9] Cattan PH, Schilling R. Les systémes arachidiers dans les zones de savanes ouest-africaines. In: Savanes d'Afriques, terres fertiles? Actes de Rencontres Internationales, Montpellier, Decembre 10-14, 1990, Ministere de la Cooperation det du Development et CIRAD, France 1990; pp.145-70.

[10] Subbarao GV, Renard C, Payne WA, Bationo A. Long-term effects of tillage, phosphorus fertilization and crop rotation on pearl milletcowpea productivity in the west-African Sahel. Exp Agric 2000; 36: 243-64.

[11] Bationo A, Rhodes E, Smaling EMA, Visker C. Technologies for restoring soil fertility. In: Mokwunye AU, Dejager EMA, Smaling. Eds. restoring and maintaining the productivity of west african sils: key to sustainable development, IFDC-Africa, LEI-DLO and SCOLO, Miscellaneous Fertilizers Studies No 14, International Fertilizer Development Center 1996. 
[12] Klaij MC, Ntare BR. Rotation and tillage effects on yield of pearl millet (Pennisetum glaucum) and cowpea (Vigna unguiculata), and aspects of crop water balance and soil fertility in a semi-arid tropical environment. J Agric Sci 1995; 124: 39-44.

[13] Bationo A, Christianson CB, Baethgen WE, Plant density and nitrogen fertilizer effects on pearl millet production in Niger. Agron J 1990; 82: 290-5.

[14] Coulibaly A, Bagayoko M, Traore S, Mason SC. Effect of crop residue and cropping system on pearl millet and cowpea yield. Afr Crop Sci J 2000; 8 (4): 411-8.

[15] Penning de Vries MA, Djiteye FWT. La productivité des pâturages sahéliens : Une étude des sols, des végétations et de l'exploitation de cette ressource naturelle, Netherlands: Centre for Agricultural Publishing and Documentation (Pudoc-DLO), Wageningen 1982.

[16] Breman H, Niamngado O. Maintien de la production agricole sahélienne (Rapport mi-chemin du projet PSS). Rapport PSS No. 6, AB-DLO/IER : Wageningen, Netherlands 1994.

[17] Bationo A, Ntare BR. Rotation and nitrogen fertilizer effects on pearl millet, cowpea and groundnut yield and soil chemical properties in a sandy soil in the semi-arid tropics, West Africa. J Agric Sci 2000; 134: 277-84.

[18] Williams TO, Powell JP, Fernandez-Rivera S. Manure availability in relation to sustainable food crop production in semi-arid west Africa: Evidence from Niger. Q J Int Agr 1995; 34(3): 248-58.

[19] Harris D. Staying in control of rainfed crops. In: Proceeding of the First Annual Scientific Conference of the SADCC / ODA Land and Water Management Programme, October 8-10, 1990, 257-262 (Eds D. E. Gollifer \& M. Kronen). Private Bag 00108, Gaborone, Botswana: SADGG-L\&WMRP (Southern African Development Coor- dination Conference-Land and Water Management Research Programme) 1992.

[20] Chambers R, Pacey A, Thrupp LA. Farmers first: farmer innovation and agricultural research. London, UK: Intermediate Technology Publications 1989.

[21] Kitch LW, Boukar O, Endondo C, Murdock LL. Farmer acceptability criteria in breeding cowpea. Exp Agr 1998; 34: 475-86.

[22] Sperling L, Locvinsohn ME, Ntabomvura B. Rethinking the farmer's role in plant breeding: local bean experts and on-station selection in Rwanda. Exp Agric 1993; 29: 509-19.

[23] Kanyama-Phiri G, Snapp SS, Minac S. Partnership with Malawian farmers to develop organic matter technologies. Outlook Agr 1998; 27: $167-175$.

[24] Snapp SS. Mother and baby trials: a novel trial design being tried out in Malawi. Target Newsletter of the Southern Africa Soil Fertility Network 1999; 17: 8 .

[25] Hiernaux P, Ayantunde A. The Fakara: a semi-arid agroecosystem under stress. Report of research activities, First phase (July 2002-June 2004) of the DMP-GEF Program. International Livestock Research Institute, 2004.

[26] Oudwater N, Martin A. Methods and issues in exploring local knowledge of soils. Geoderma 2003; 111: 387-401.

[27] ICRISAT. Grey to green revolution. ICRISAT annual report Patancheru, Andhra Pradesh, India 2001; pp. 1-48.

[28] Tabo R, Bationo A, Maimouna DK, Hassane O, Koala S. Fertilizer micro-dosing for the prosperity of small-scale farmers in the Sahel. Final report, Global Theme on Agroecosystems Report No. 23, ICRISAT, Niamey, Niger 2006.

Received: December 05, 2014

Revised: February 17, 2015

Accepted: February 18, 2015

(C) Omae et al.; Licensee Bentham Open.

This is an open access article licensed under the terms of the Creative Commons Attribution Non-Commercial License (http://creativecommons.org/licenses/by-nc/3.0/) which permits unrestricted, non-commercial use, distribution and reproduction in any medium, provided the work is properly cited. 